Portland State University

PDXScholar

\title{
What Makes Cents? How Uber Shapes Municipal On- Street Parking Revenue
}

Anne Brown

University of Oregon

Benjamin Y. Clark

University of Oregon, bclark2@uoregon.edu

Follow this and additional works at: https://pdxscholar.library.pdx.edu/trec_reports

Part of the Transportation Commons, Urban Studies Commons, and the Urban Studies and Planning Commons

Let us know how access to this document benefits you.

\section{Recommended Citation}

Brown, Anne and Benjamin Y. Clark. What Makes Cents? How Uber Shapes Municipal On-Street Parking Revenue. NITC-2016-UO-15. Portland, OR: Transportation Research and Education Center (TREC), 2020. https://dx.doi.org/10.15760/trec.252

This Report is brought to you for free and open access. It has been accepted for inclusion in TREC Final Reports by an authorized administrator of PDXScholar. Please contact us if we can make this document more accessible: pdxscholar@pdx.edu. 


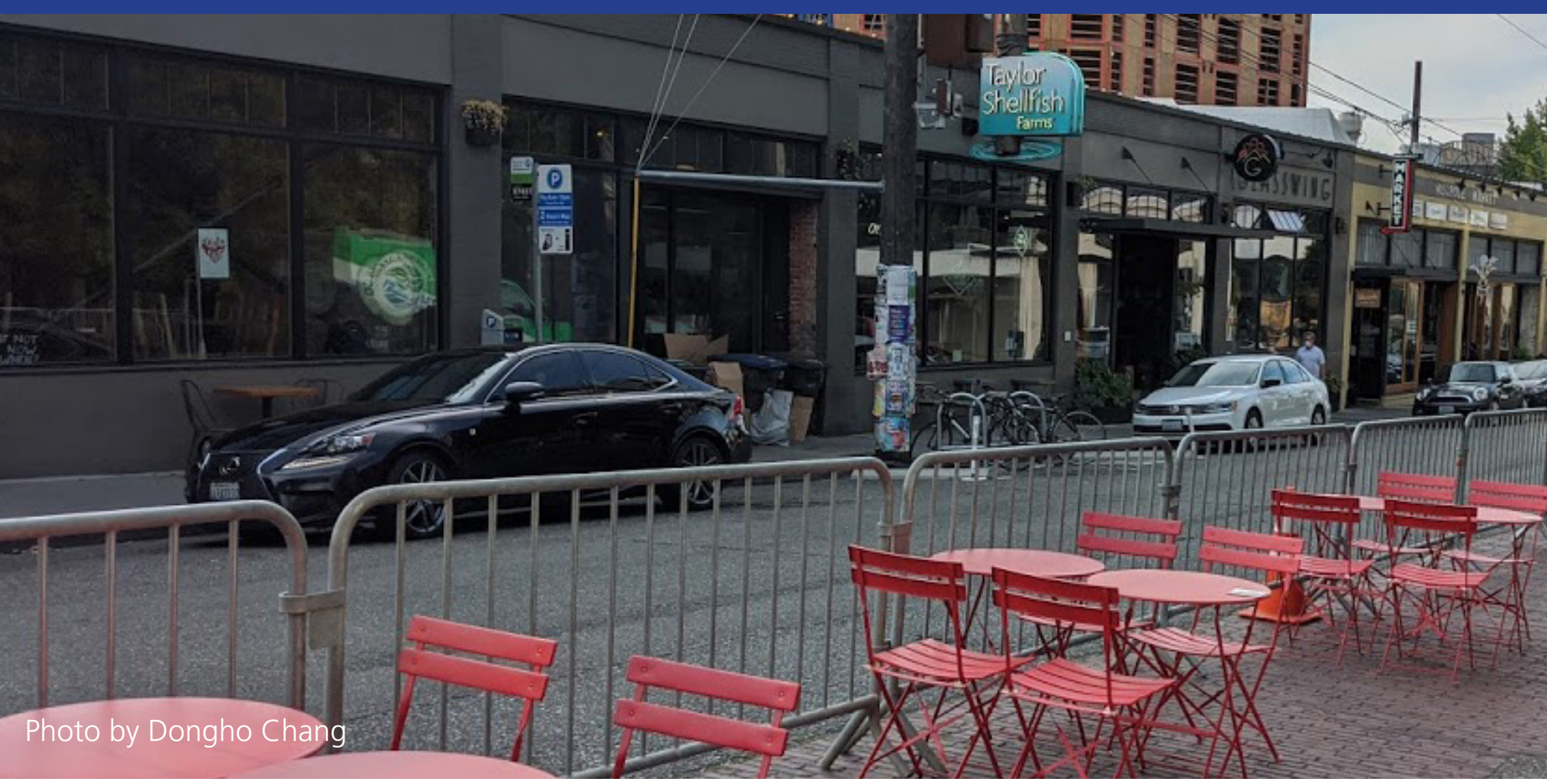

\section{What Makes Cents? How Uber Shapes Municipal On-Street Parking Revenue}

Benjamin Clark, Ph.D.

Anne Brown, Ph.D.

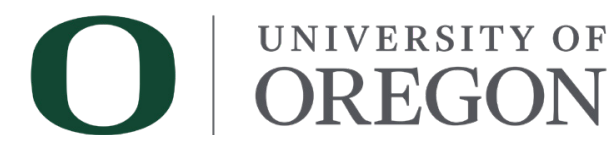




\title{
WHAT MAKES CENTS? HOW UBER SHAPES MUNICIPAL ON-STREET PARKING REVENUE
}

\author{
Final Report \\ NITC-RR-1215
}

by

\author{
Anne Brown \\ Assistant Professor \\ School of Planning, Public Policy and Management \\ University of Oregon \\ abrown33@uoregon.edu \\ iD orcid.org/0000-0001-5009-8331 \\ Benjamin Y. Clark \\ Associate Professor \\ School of Planning, Public Policy and Management \\ University of Oregon \\ bclark2@uoregon.edu
}

Dorcid.org/0000-0002-8627-7857

for

National Institute for Transportation and Communities (NITC)

P.O. Box 751

Portland, OR 97207
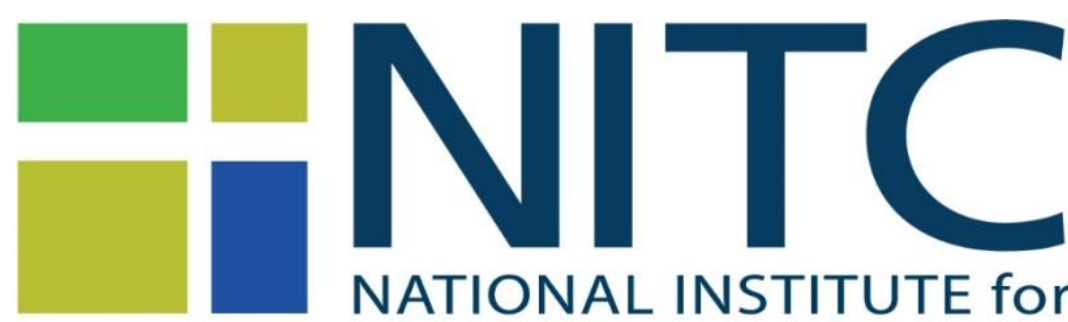

NATIONAL INSTITUTE for

TRANSPORTATION and COMMUNITIES

August 2020 


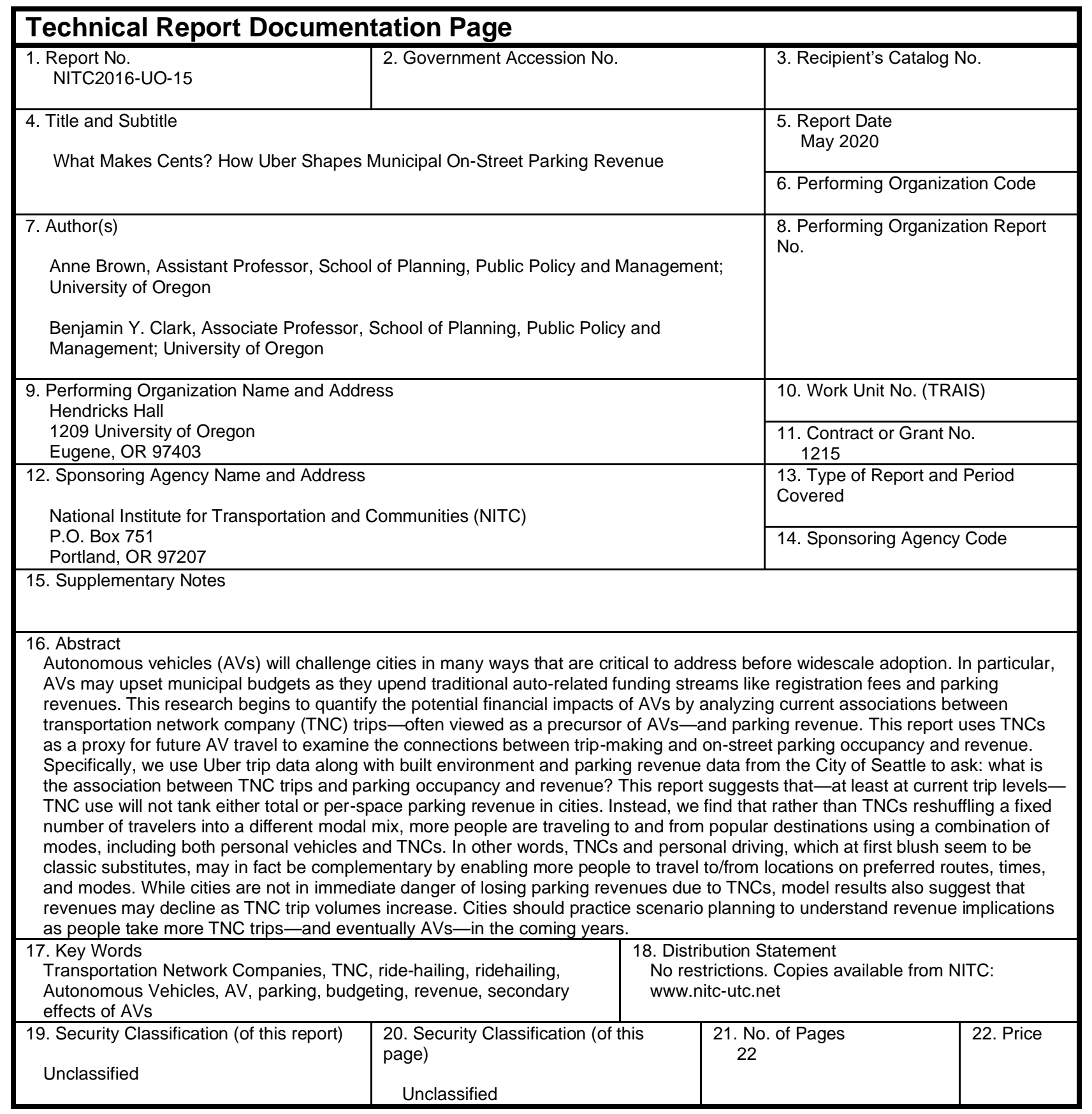




\section{ACKNOWLEDGEMENTS}

This project was funded by the National Institute for Transportation and Communities (NITC2016-UO-15 (2106DR-39972)), a U.S. DOT University Transportation Center.

We thank Jay Matonte for his diligent work collecting data and phenomenal mapping of Seattle. Thanks also to Mary Catherine Snyder with the City of Seattle Department of Transportation for her attention, insight, and guidance throughout the project.

\section{DISCLAIMER}

The contents of this report reflect the views of the authors, who are solely responsible for the facts and the accuracy of the material and information presented herein. This document is disseminated under the sponsorship of the U.S. Department of Transportation University Transportation Centers Program in the interest of information exchange. The U.S. Government assumes no liability for the contents or use thereof. The contents do not necessarily reflect the official views of the U.S. Government. This report does not constitute a standard, specification, or regulation.

\section{RECOMMENDED CITATION}

Brown, Anne and Benjamin Y. Clark. What Makes Cents? How Uber Shapes Municipal On-Street Parking Revenue. NITC2016-UO-15. Portland, OR: Transportation Research and Education Center (TREC), 2020. 


\section{TABLE OF CONTENTS}

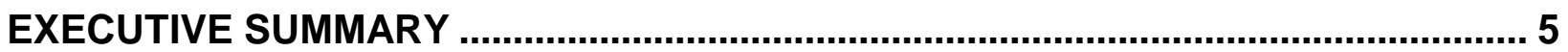

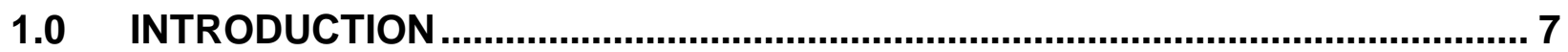

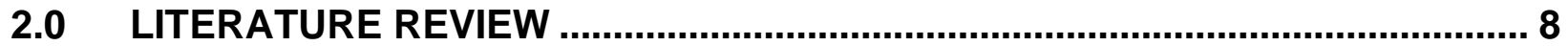

2.1 EFFECTS OF AVS ON MUNICIPAL BUDGETS ........................................... 8

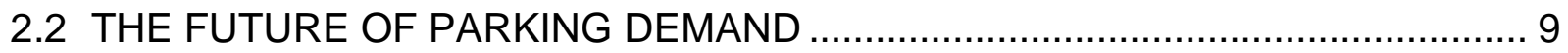

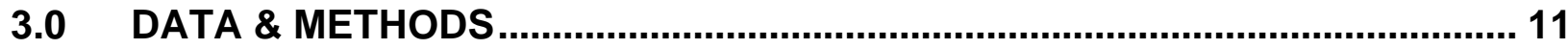

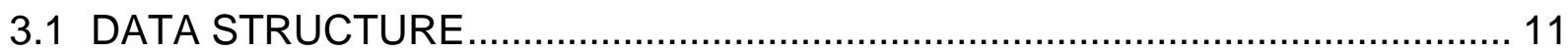

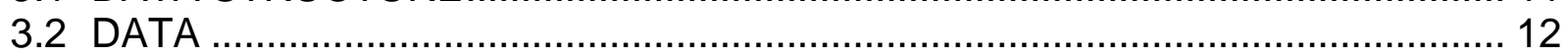

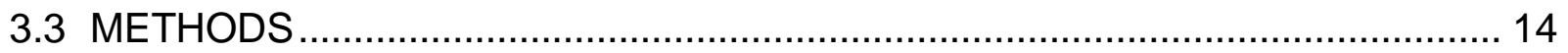

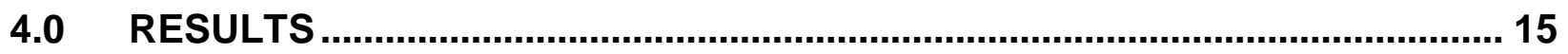

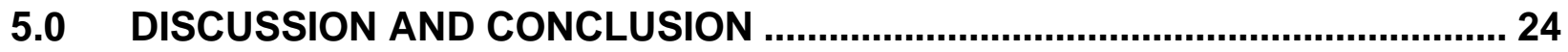

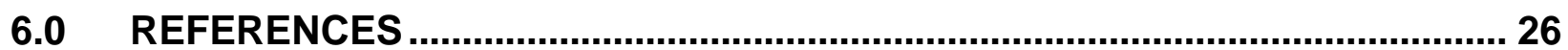

\section{LIST OF TABLES}

Table 4.1: Associations between TNC trips, neighborhood characteristics and (1) parking occupancy, (2) total parking revenue, and (3) average parking revenue per space.

\section{LIST OF FIGURES}

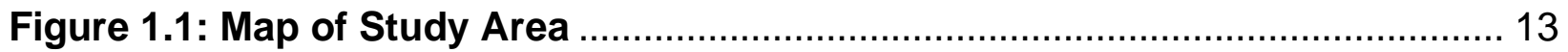

Figure 4.1: TNC Trip Effects on Parking Occupancy ........................................ 17

Figure 4.2: TNC Trip Effects on Total Tract Revenue …..................................... 18

Figure 4.3: TNC Trip Effects on Average Revenue Per Parking Space .................. 19

Figure 4.4: Hourly Price to Park Effects on Tract Revenue by Time of Day ........... 20

Figure 4.5: Number of Off-Street Parking Spaces Effects on Total Tract Revenue

Figure 4.6: Associations between Transit Stops Per Square Mile and Per-Space

Parking Revenue by Time of Day ............................................................... 22 


\section{EXECUTIVE SUMMARY}

Autonomous vehicles (AVs) will challenge cities in ways that are currently difficult to fully envision, and yet critical to begin addressing. A particular challenge is the potential for $A V s$ to upset municipal budgets as they upend traditional auto-related funding streams like registration fees and parking revenues. This research begins to quantify the potential financial impacts of AVs by analyzing current associations between transportation network company (TNC) trips-often viewed as a precursor of AVs-and parking revenue. Specifically, we use Uber trip data along with built environment and parking revenue data from the City of Seattle to ask: what is the association between TNC trips in a neighborhood and parking occupancy and revenue?

We find that the number of TNC trips is positively and significantly associated with parking occupancy and revenue; specifically, for each additional 1,000 TNC trips, parking occupancy increases by 17.1 percent, all else equal. For the same increase in TNC trips, total and per-space parking revenue increases by 15.4 and 12.7 percent, respectively. Yet findings reveal that the relationship between TNC trips and parking occupancy and revenue is not linear; the model predictions show that parking revenues will decline if or when TNC (or possibly AV) trips are about three times greater than the average number of daily trips taken in 2016. The maximum observed parking occupancy rates also indicate that we are closer to peak parking (revenue) than these predictions would otherwise indicate.

This suggests that, while some travelers may hail a TNC in lieu of driving, modal substitution is not yet resulting in parking revenue losses overall, although it is getting closer. Instead, rather than TNCs reshuffling a fixed number of travelers into a different modal mix-more people are traveling to and from destinations using a combination of modes, including both personal vehicles and TNCs. In other words, TNCs and driving, which at first blush seem to be classic substitutes, may in fact be complementary by enabling more people to travel to/from locations on preferred routes, times, and modes.

The data used in this study do not provide insight into which TNC trips substitute for driving, which carry people who previously traveled by other modes or at other times of the day, or which are new trips entirely. Additional research is needed to better understand the potential mode shift dynamics between driving, TNCs, and other modes.

TNCs are just one of many factors significantly associated with parking occupancy and revenue; parking occupancy and revenue are also associated with local built environment, temporal, and transportation system contextual variables. Model results for both total and per-space revenue show that the built environment, including land use and population density, have relatively small associations with revenue compared to the broader temporal and transportation context: time of day, number of parking spaces, and parking price all have strong associations with parking revenue. This finding affords 
a policy opportunity across land uses. Policymakers and planners can adjust parking prices or policies by time of day or day of week to achieve desired occupancies or outcomes.

This research demonstrates that while cities are not in immediate danger of losing parking revenues due to TNCs, and parking demand will not disappear overnight, parking revenues may erode at high levels of TNCs or AV trip-making. To prepare for this uncertain future, cities should practice scenario planning to understand revenue implications as people take more TNC trips-and eventually AVs-in the coming years. Dynamic analyses are needed to assess how parking rates change in response to higher TNC use, and how those changes paired with one another could affect parking revenues. 


\subsection{INTRODUCTION}

Twenty years ago, autonomous vehicles (AVs) were more fiction than science. Today, AVs have driven millions of miles, but continue to face planning, design, and financial challenges (Brodsky, 2016; Glancy, 2015). AVs hold the potential to drastically reshape transportation and could reshuffle city development patterns or alter land valuation, leading to strains on government finances. However, the current level of AV deployment remains insufficient to evaluate how they may actually impact city environments and, in particular, city budgets. Instead, researchers and policymakers have thus far relied on transportation network companies (TNCs), including Uber, to proxy for forthcoming AV technologies. Like AVs, TNCs eliminate the need to park at a destination. Previous researchers have also used chauffeur services_-similar to TNCs-to approximate potential travel behavior responses to the introduction of AVs (Harb et al., 2018).

A proliferation of research has explored many technological aspects of AVs, yet few cities have begun planning for or considering how AVs may impact city or suburban life (Glancy, 2015; Mitteregger et al., 2019; Terry and Bachmann, 2019; Freemark, Hudson, and Zhao, 2019). This report evaluates a specific secondary effect: the potential impacts of $A V s$ on municipal budgets via altered parking revenues. By eliminating the need to park, AVs have the potential to decimate parking revenues so that parking garages and meters are not only no longer sustainable sources of revenue, but liabilities as revenues fall below levels needed to repay debts incurred to build the parking infrastructure in the first place. Using TNC (Uber) trip data in conjunction with built environment and parking revenue data from the City of Seattle, we ask: what is the association between TNC trips and parking occupancy and revenue? Findings yield implications for municipal budgets and AV and parking policy moving forward.

The remainder of this report is arranged as follows: First, we review the pertinent literature on municipal budgets, TNCs, AVs, and parking. Second, we overview the data and methods used to answer our research question. Next, we discuss the results of our investigation. We close with implications for city budgets and AV and parking policy moving forward. 


\subsection{LITERATURE REVIEW}

\subsection{EFFECTS OF AVS ON MUNICIPAL BUDGETS}

Limited work to date has investigated the impacts of AVs or TNCs on municipal finance and budgeting. Clark, Larco, and Mann (2017) provide an overview of potential AV impacts across a city budget, but propose a directional rather than quantified magnitude of these impacts. In a three-city case study, Clark and Lewis (2018) elucidate limited budgetary impacts across a number of revenue categories, but do not base their empirical evaluation of what is currently happening on the ground. Mitteregger et al. (2019) examine projected fiscal impacts of AVs on Vienna, Austria. Maciag (2017) is one of the few articles in the popular press to empirically examine how autonomous vehicles might impact local government budgets. In his study of 25 large U.S. cities, he observes that parking revenues (meters, garages, fines/fees) amount to $\$ 129$ per capita on average. He notes that revenue "[t]otals were much larger in cities assessing special taxes on parking operators, deploying traffic cameras or those receiving substantial shared revenues from states in the form of gas taxes or vehicle registration fees" (Maciag, 2017). This implies that the degree to which cities rely on parking- and enforcement-related revenues will ultimately affect how much a city's budget will be impacted by the shift to AVs.

A number of AV policy guides have been distributed in the past several years. Glus et al.'s (2017) "Driverless Future: A Policy Roadmap for City Leaders" discusses how cities may change over the coming decades with the adoption of $A V s$, and issues recommendations for how cities might plan for such changes. They state that "Cities have a window of opportunity to shape how the autonomous vehicle is used and must act now to define policies that minimize risks and maximize the benefits of driverless technology" (Glus et al., 2017, 2). While the authors provide a range of recommendations, they only briefly mention AVs' potential financial impacts. Fagnant and Kockelman (2015) examine "traffic safety, congestion, and travel behaviors," and while they suggest future changes to local governments' costs and revenues, they offer little beyond demonstrating a need for additional planning and research. Lewis et al. (2017) offer a roadmap for leaders at all levels of U.S. government, but only briefly address changes in costs and revenues and do not provide sufficient detail to be actionable by local leaders. Connery (2016) analyzes the impacts of AVs on the municipal bond market, focusing on the investment risks of general obligation bonds as they relate to AVs. The National League of Cities (NLC) (2017) issued a local government "policy preparation guide" that presents answers to common questions for cities about AV technologies and issues some guidance for cities preparing for AVs. The guide calls for proactive local policies and coordination across jurisdictional boundaries, with metropolitan planning organizations coordinating regional efforts. Similar to other reports, the NLC offers only a broad call to cities for investing in the future and cautions that changes to expenditures and revenues are coming. The report, however, offers little specific advice or insight on where budgetary changes may occur. The City of Seattle issued its own guide, called the "New Mobility Playbook," which 
highlighted the need to diversify revenue sources in response to AVs (Seattle Department of Transportation, 2017). The City outlined a number of next steps to prepare for all types of new mobility, including AVs. Seattle's work makes it clear they are aware change is happening, but again, they do not project the magnitude of change. While AVs will undoubtedly impact both sides of their budget (expenditures and revenues), the literature to date provides very limited insight into the magnitude of AVs' potential financial impacts or how cities should start fiscal and budget planning for AVs.

\subsection{THE FUTURE OF PARKING DEMAND}

Many argue that, today, cities err on the side of requiring too much parking (Shoup, 2017; Willson, 2013). Most parking in Seattle, the city analyzed in this report, is free from direct user fees. Parking on most city streets is free, at least to those who live there, and often even free to others for certain hours each day. Yet as Shoup (2017) has detailed, even free parking is far from free.

The actual cost of a single surface parking space averages $\$ 24,000$ and can range from nearly zero to more than $\$ 100,000$ (Shoup, 2011; 2017); however, these are not the prices the public typically pays for use of these spaces. Shoup $(2011,185)$ estimates that debt service and operations translate into monthly costs of $\$ 127$ per parking structure space, although this estimate would roughly double if it included the social and opportunity costs of parking. A quick scan of current monthly rates for parking in Seattle show that users pay between $\$ 190$ to more than $\$ 300$ per month for a reserved spot in areas similar to where on-street parking is metered by the city, though rates do vary widely.

Gutman (2018) investigated new garage parking in and around the Seattle metro region, finding that new parking construction costs total nearly $\$ 50,000$ per spot. Based on the replacement cost of parking spaces, Scharnhorst $(2018,21)$ estimated that the "per-car cost of parking for the 435,000 cars in Seattle is $\$ 82,281$," which totals more than $\$ 35$ billion.

Parking policy has a long history of shaping American cities. With the advent of offstreet parking in the 1930s, "urban planners began to assume that most people would travel everywhere by car, park on-site while they worked, shopped, or dined, and then drive on to their next destination" (Shoup 2017, 2). The advent of AVs, however, breaks the historical nexus between driving and parking, reducing the need for on- and offstreet parking. Research on TNCs suggests a range of possible futures for parking demand in an autonomous future. Anecdotal evidence suggests falling parking revenues alongside the rise of TNCs (Maciag, 2017; Bergal, 2017b; 2017a; Williamson, 2018; Morris, 2018). Correspondingly, surveyed TNC riders report hailing a ride to avoid parking prices and congestion (Clewlow and Mishra, 2017; Henao, 2017). While some research suggests that TNC use could reduce driving trips and therefore parking demand-particularly at popular destinations such as airports, sports arenas, and bar and nightlife areas (Henao and Marshall, 2019)—one may also expect to see more TNC 
trips in locations with high parking demand as people seek to avoid driving to and parking in such areas. For example, Brown (2019) finds a negative association between off-street parking density-where arguably parking supply is greater and a free space is easier to find-and the number of TNC (Lyft) trips per capita. TNC trips are also associated with built environment features beyond parking: research repeatedly identifies positive connections between density and ride-hail travel (Brown, 2019; Mahmoudi and Zhang, 2009; San Francisco County Transportation Authority, 2017). Mixed land uses are also associated with greater demand for for-hire services (including taxi, Uber, and Lyft) (Mahmoudi and Zhang, 2009).

Like TNCs, AVs hold the potential to dramatically affect parking demand and therefore revenues. As Clark and Lewis (2018) and Maciag (2017) note, AVs will reduce parking revenue, though the timing of this decline remains uncertain. Some predict fully functional autonomous and shared ride-hailing services (Lyft without a driver) within 20 years. While two decades may seem like sufficient time for cities to plan and adapt to $\mathrm{AVs}$, research also finds that few are planning or preparing for these technologies (Freemark, Hudson, and Zhao, 2019). What are cities to do if and when shifts from personal cars to hailed $\mathrm{AV}$ fleets decimate parking revenues so that garages and meters are no longer sustainable sources of revenue, and indeed, a financial liability? In the following sections, we discuss, ask, and answer: What is the association between TNC demand and parking occupancy and revenue in Seattle between 2013 and 2016? 


\subsection{DATA \& METHODS}

This research examines TNC trips and parking occupancy and revenue in Seattle between 2013 and 2016. On-street parking accounts for approximately one-third of total parking spaces in the city; the other two-thirds are in private garages, surface lots, and driveways. In sum, the city has about 1.6 million parking spaces, or about five parking spaces per household and nearly 30 parking spaces per acre, on average, throughout the city. Seattle's parking supply is ample, and more similar to less-dense Des Moines, IA (which has fewer parking spaces per acre than Seattle) than it is to the more densely populated cities of New York and Philadelphia (Scharnhorst, 2018). In other words, parking, in all of its forms, is ample in Seattle.1

This research utilizes parking occupancy, parking revenue, and TNC trip data along with data on the local built environment to examine the association between parking revenue and TNC trips in Seattle between January 2013 and December 2016. January 2013 represents the start of Uber operations in Seattle at volumes sufficient to track in our data (at least five trips in a census tract per time period (e.g., 11 a.m.-3 p.m.)); December 2016 represents the most recent date that Uber was willing to provide trip data to this study. The data used in this research are described in depth below.

\subsection{DATA STRUCTURE}

The geospatial and statistical analysis were challenged by the large size of the on-street parking data (approximately 560GB) provided by the Seattle Department of Transportation (SDOT). Given the computational challenges of working with these data, we chose to collapse the data to speed up computing times and provide for simple explanations in our study, while still having sufficient explanatory power.

We use census tracts as the geographical units of study. In each tract we use three time periods (morning [8-10 a.m.], afternoon [11 a.m.-3 p.m.], and evening [4-7 p.m.]) for each day of the week (Monday-Saturday; parking is free on Sundays) in a given month. This means that all estimates would be, for example, calculated to afternoons on Tuesdays in March in the year 2013. This translates to three time periods per day each of the six days of the week we observed (Monday-Saturday), for each month-resulting in 18 observations per tract per month. The resulting study sample size is 24,598 observations. Each study year (2013-2016) makes up 20 to 26 percent of the sample.

1 Parking spots are not always free of charge, nor are they always readily available within feet of the destination, which may give the perception to some that parking is scarce in Seattle. This phenomenon is by no means isolated to Seattle; it is seen across the U.S. 


\subsection{DATA}

SDOT Data: We use two datasets from SDOT in our study. The first dataset includes paid parking transactions from districts with paid on-street parking (see

Figure 1). Parking transaction data allow us to calculate the revenue collected. The second dataset is the calculated median occupancy rate for each tract. The median value of occupancy in a time block was calculated by the authors from data the city provided. For both datasets, we used ArcGIS to geolocate parking data. We then calculated parking occupancy and revenue for each observation period to match our overall data structure described above. Median occupancy rate is subject to a degree of inaccuracy, however, as people can pay for more meter time than they use (i.e., depart a meter before their time has expired) or pay for less than they actually use (i.e., park at a meter without paying). Similar to what Clark $(2019,12)$ notes about this calculation "it is assumed that this pattern of over/underpayment will be evenly distributed across all parking areas." We also calculated the average rate paid in each tract for a given time period. Average on-street parking price per hour in a tract accounts for Seattle's policy of periodically adjusting rates to optimize parking occupancy.2

2 Like many other cities, Seattle's parking policy has a goal of occupancy rates 70-85 percent (Baruchman, 2018). Shoup (2017) identified 85percent occupancy rate as an ideal occupancy rate to reduce congestion associated with drivers cruising for available on-street parking. 


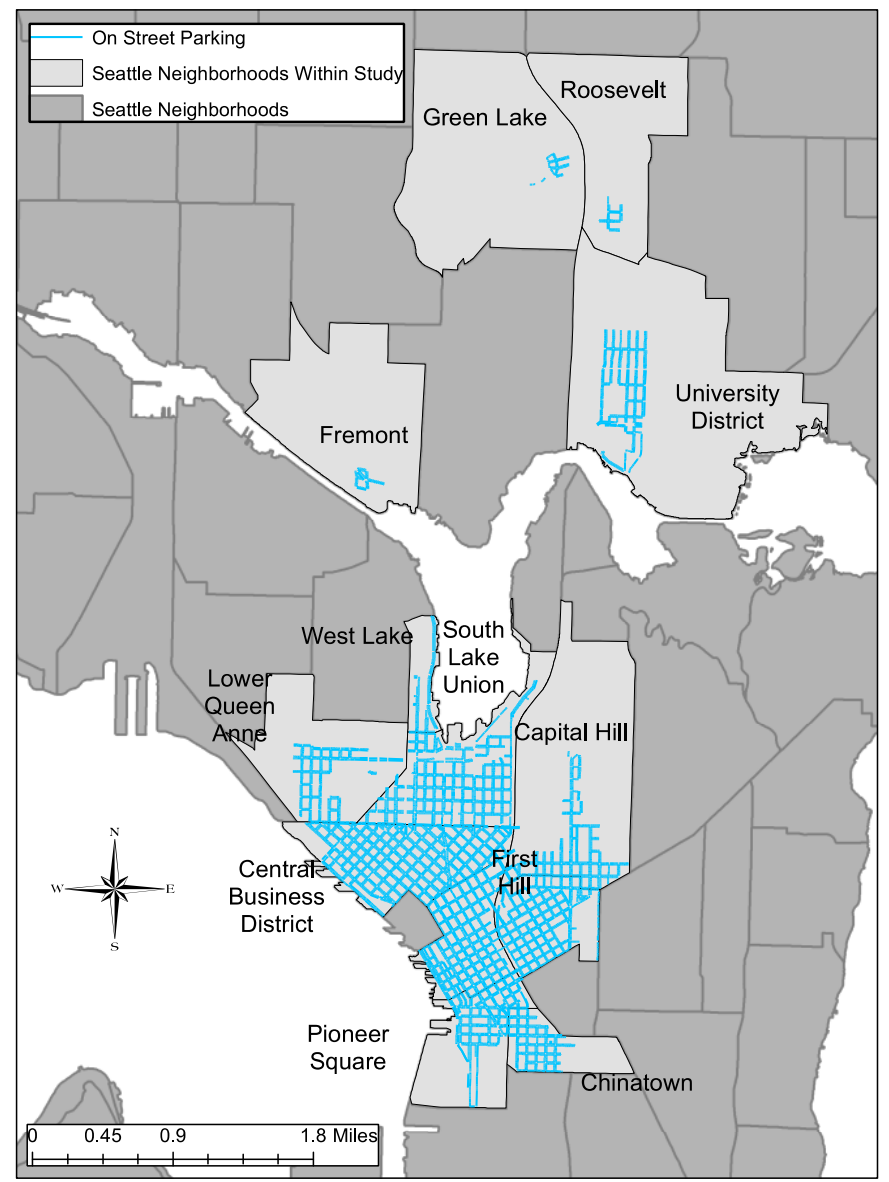

Figure 1.1: Map of Study Area

INC Data: Uber provided census tract-level trip count data; specifically, we utilize the total number of trip starts and ends in a tract. Trips are only counted once if they start and end in the same tract. Given the exponential growth of TNC trips during the time period, we include the number of trips and the squared number of trips to account for a potential non-linear relationship in TNC growth.

U.S. Census Bureau American Community (ACS) Survey Data: Data drawn from the ACS include car ownership, population density, and median household income. We use census tract-level data from the five-year average data files-a separate five-year average matching each year of the study. For example, we used the five-year 20122016 American Community Survey for our 2016 observations.

Parking Citations: Parking violations could affect travelers' decisions to use Uber instead of driving oneself. We therefore filed a public records request from the City of Seattle to obtain parking citation data to account for this possibility. Seattle provided data for 2016 and 2017-the only available years of data. We geolocated each violation to the census tract and time period, then calculated the average revenue across both 
years. The two-year averages are used across all study years, as individual year observations were not available.

Off-Street Parking Inventory: Seattle Open Data provides maps and detailed data of private off-street paid parking inventory. We geolocated each parking lot to census tracts. We assume the off-street parking inventories are static across the study period.

Land Use Mix: Prior literature has indicated that land use is associated with changes in demand for TNCs and for-hire vehicles (Mahmoudi and Zhang, 2009; Clark and Brown, 2020). We therefore gathered land use data from the City of Seattle. We consolidated different land use codes into five groups for our analysis: commercial, industrial, residential, mixed, and all other uses. We then calculated the share of land uses for each census tract using ArcGIS. Land uses change each year; thus, we calculated a unique land use variable for each year of our study.

Transit Stop Density: Public transportation in Seattle and the broader King County area offers travel alternatives to driving. Past research finds transit stop density has a strong association with TNC trip-making. For example, Brown (2019) finds that, in Los Angeles, a 10 percent increase in the number of transit stops per square mile was associated with a 2.5 percent increase in TNC trips traveling to or from a neighborhood. Consequently, we incorporate transit stop density to reflect previous research and to quantify the broader context of the transportation network. We obtained King County Metro transit stop data from King County's open data portal. We then geocoded these transit stops and calculated their density within each census tract.

\subsection{METHODS}

In this report we model associations between TNC trips, neighborhood built environment and three dependent parking variables: 1) on-street parking occupancy in a census tract; 2) total on-street parking revenue in a census tract; and 3) average parking revenue per space in a census tract. For all three dependent variables, we specify Poisson regression models with robust standard errors as all three dependent parking variables have non-normal or skewed distributions. Consequently, we follow the direction of Wooldridge (2002) and Gould (2011) to best account for these distributions. Gould has noted that the use of "Huber/White/Sandwich linearized estimator of variance is a permissible alternative to log linear regression." A Poisson specification has an added value of keeping zero revenue or zero occupancy observations; by contrast, an ordinary least squares (OLS) model with a logged dependent variable would drop those observations without further transformations. Furthermore, Silva \& Tenreyro $(2006,645)$ state that in using a Poisson model, rather than OLS, "what is more important, yi does not even have to be an integer-for the estimator based on the Poisson likelihood function to be consistent." Consequently, we have confidence that the Poisson model is the appropriate methodological approach for the data we are using. 


\subsection{RESULTS}

The results from this report expand our knowledge about the associations between TNC trips and parking. While the analysis is focused on TNCs and parking, the models forecast the role parking may play in the world of autonomous vehicles. Table 4.1 shows the results from our three models. Model 1 uses median parking occupancy as the dependent variable. Model 2 uses total tract parking revenue. And Model 3 uses the average revenue per parking space. Throughout this section, we present results graphically to aid in interpretation of model coefficients.

We first focus on model results of the independent variables of primary interest: the number of Uber trips. The results from Model 1 show that the number of Uber trips is positively and significantly associated with parking occupancy. The positive association is mediated by a negative squared term. For each 1,000 additional TNC trips, parking occupancy is expected to increase by 17.1 percent, all else equal. Figure 4.1 shows the non-linear nature of the association between parking occupancy and TNC trips. The positive relationship between TNC trips and parking occupancy peaks and then dips; in all cases, the negative relationship begins before projections reach the maximum observed value of TNC trips, depicted as a dashed vertical line. In all instances, these relationships assume no policy changes have been taken by the City to increase occupancy, such as changing hourly on-street parking prices.

A positive and statistically significant association also exists between TNC trips and total tract revenue: each 1,000 additional trips yields a 15.4 percent increase in revenue, all else equal. Figure 4.2 shows predicted model values for total tract revenue as a factor of TNC trips. As with parking occupancy, the squared number of trips is statistically significant and negative. When we examine the marginal effects of TNC trips on total parking revenue, we find statistically significant results for a range of predicted outcomes up to about 13,750 trips. 
Table 4.1: Associations between TNC trips, neighborhood characteristics and (1) parking occupancy, (2) total parking revenue, and (3) average parking revenue per space

\begin{tabular}{|c|c|c|c|c|c|c|c|c|c|}
\hline \multirow[b]{3}{*}{ All pick-ups and drop-offs (in 1000s) } & \multicolumn{3}{|c|}{ (1) } & \multicolumn{3}{|c|}{ (2) } & \multicolumn{3}{|c|}{ (3) } \\
\hline & $\begin{array}{c}\mathrm{DV}= \\
\text { Occupancy } \\
\text { Rate }\end{array}$ & se & $\begin{array}{c}\text { \% change in } \\
\text { expected count } \\
\text { for unit change in } \\
X\end{array}$ & $\begin{array}{c}\text { DV=Total } \\
\text { Parking } \\
\text { Revenue }\end{array}$ & se & $\begin{array}{l}\% \text { change in } \\
\text { expected } \\
\text { count for unit } \\
\text { change in } X\end{array}$ & $\begin{array}{l}\text { DV=Parking } \\
\text { Revenue } \\
\text { Per Space }\end{array}$ & se & $\begin{array}{l}\text { \% change in } \\
\text { expected } \\
\text { count for unit } \\
\text { change in X }\end{array}$ \\
\hline & $0.17751^{\star \star}$ & [0.00956] & 19.4 & $0.16014^{\star \star}$ & [0.01312] & 17.4 & $0.12977^{\star \star}$ & [0.01002] & 13.9 \\
\hline All trips squared (in 1000s) & $-0.02311^{* *}$ & [0.00171] & -2.3 & $-0.01459^{* *}$ & [0.00174] & -1.4 & $-0.01165^{\star *}$ & [0.00139] & -1.2 \\
\hline $\begin{array}{l}\text { On-Street Parking Median Occupancy } \\
\text { Rate }\end{array}$ & & & & $0.02267^{\star \star}$ & [0.00030] & 2.3 & $0.02364^{\star *}$ & [0.00028] & 2.4 \\
\hline Average cost to park on-street per hour & $-0.05701^{\star *}$ & [0.00437] & -5.5 & $0.17183^{\star \star}$ & {$[0.00865]$} & 18.7 & $0.39309^{* *}$ & {$[0.00698]$} & 48.2 \\
\hline Paid On-Street Parking Spaces (in 100s) & $-0.04376^{\star \star}$ & [0.00134] & -4.3 & $0.26802^{\star \star}$ & {$[0.00231]$} & 30.7 & $-0.04424^{\star *}$ & {$[0.00201]$} & -4.3 \\
\hline Paid Off-Street Parking spaces (in 100s) & $-0.00406^{* *}$ & [0.00012] & -0.4 & $-0.00160^{* *}$ & [0.00022] & -0.2 & 0.00011 & {$[0.00016]$} & 0 \\
\hline $\begin{array}{l}\text { Number of Vehicles -Cars, Trucks, Vans } \\
\text { (in 100s) }\end{array}$ & $-0.00928^{* *}$ & {$[0.00065]$} & -0.9 & $-0.02151^{\star *}$ & {$[0.00113]$} & -2.1 & $-0.01406^{\star *}$ & [0.00092] & -1.4 \\
\hline King County Transit Stops/Sq Mile & $-0.11906^{* *}$ & [0.00291] & -11.2 & $0.14701^{* *}$ & [0.00488] & 15.8 & $-0.10839^{\star *}$ & [0.00403] & -10.3 \\
\hline Number of Parking Citations (in 100s) & $0.05596^{\star *}$ & {$[0.00201]$} & 5.8 & $-0.01133^{* *}$ & {$[0.00264]$} & -1.1 & $-0.03290^{* *}$ & {$[0.00240]$} & -3.2 \\
\hline Median Household Income (in $\$ 1000$ s) & $0.00684^{\star *}$ & [0.00021] & 0.7 & $-0.01120^{\star \star}$ & {$[0.00036]$} & -1.1 & $-0.00099^{* *}$ & [0.00029] & -0.1 \\
\hline \multicolumn{10}{|l|}{$\begin{array}{l}\text { Zoning \& Land Use (Omitted Group: } \\
\text { Commercial) }\end{array}$} \\
\hline \% Residential & $-0.00630^{* *}$ & {$[0.00021]$} & -0.6 & $-0.00378^{* *}$ & [0.00033] & -0.4 & $-0.00094^{* *}$ & {$[0.00025]$} & -0.1 \\
\hline$\%$ Industrial & $-0.00593^{\star *}$ & {$[0.00026]$} & -0.6 & $0.00486^{\star *}$ & [0.00039] & 0.5 & 0.00047 & [0.00032] & 0 \\
\hline$\%$ Mixed Use & $0.00976^{* *}$ & {$[0.00020]$} & 1 & $-0.01800^{\star *}$ & {$[0.00035]$} & -1.8 & $0.00357^{\star *}$ & {$[0.00026]$} & 0.4 \\
\hline$\%$ Other Zoning/Use & $-0.00401^{* *}$ & {$[0.00021]$} & -0.4 & $-0.01109^{\star \star}$ & {$[0.00026]$} & -1.1 & $-0.00281^{* *}$ & [0.00022] & -0.3 \\
\hline \multicolumn{10}{|l|}{$\begin{array}{l}\text { Time of Day (Omitted Group: Morning [8- } \\
10 \mathrm{am}] \text { ) }\end{array}$} \\
\hline Afternoon (11-3) & $0.94836^{* *}$ & {$[0.00839]$} & 158.1 & $0.20679^{\star \star}$ & {$[0.01380]$} & 23 & $0.37295^{\star \star}$ & {$[0.01415]$} & 45.2 \\
\hline Evening (4-7) & $0.98842^{* *}$ & {$[0.00888]$} & 168.7 & $-0.71165^{\star *}$ & [0.01485] & -50.9 & $-0.54050^{* *}$ & [0.01609] & -41.8 \\
\hline \multicolumn{10}{|l|}{$\begin{array}{l}\text { Day of the Week (Omitted Group: } \\
\text { Monday; no paid parking Sundays) }\end{array}$} \\
\hline Tuesday & $0.06403^{\star *}$ & {$[0.00805]$} & 6.6 & $0.07163^{\star *}$ & {$[0.01424]$} & 7.4 & $0.07384^{\star *}$ & {$[0.01180]$} & 7.7 \\
\hline Wednesday & $0.08887^{* *}$ & {$[0.00799]$} & 9.3 & $0.05932^{* *}$ & {$[0.01426]$} & 6.1 & $0.06175^{\star *}$ & {$[0.01177]$} & 6.4 \\
\hline Thursday & $0.10806^{* *}$ & {$[0.00796]$} & 11.4 & $0.03392^{*}$ & {$[0.01454]$} & 3.5 & $0.03190^{\star *}$ & [0.01203] & 3.2 \\
\hline Friday & $0.12537^{\star *}$ & {$[0.00806]$} & 13.4 & $0.04071^{\star *}$ & {$[0.01430]$} & 4.2 & $0.03414^{\star *}$ & {$[0.01185]$} & 3.5 \\
\hline Saturday & $0.07823^{\star *}$ & {$[0.00950]$} & 8.1 & $0.08623^{\star *}$ & {$[0.01367]$} & 9 & 0.00507 & {$[0.01247]$} & 0.5 \\
\hline Year Trend & $-0.05066^{\star *}$ & [0.00383] & -4.9 & $-0.03515^{\star *}$ & {$[0.00555]$} & -3.5 & $-0.07357^{* *}$ & [0.00433] & -7.1 \\
\hline Constant & $104.70918^{* *}$ & [7.72492] & & $77.96304^{* *}$ & [11.17747] & & $154.09079^{\star *}$ & {$[8.72650]$} & \\
\hline Observations & 24,598 & & & 24,598 & & & 24,598 & & \\
\hline Robust standard errors in brackets & \multicolumn{9}{|c|}{${ }^{* *} p<0.01,{ }^{*} p<0.05$} \\
\hline
\end{tabular}



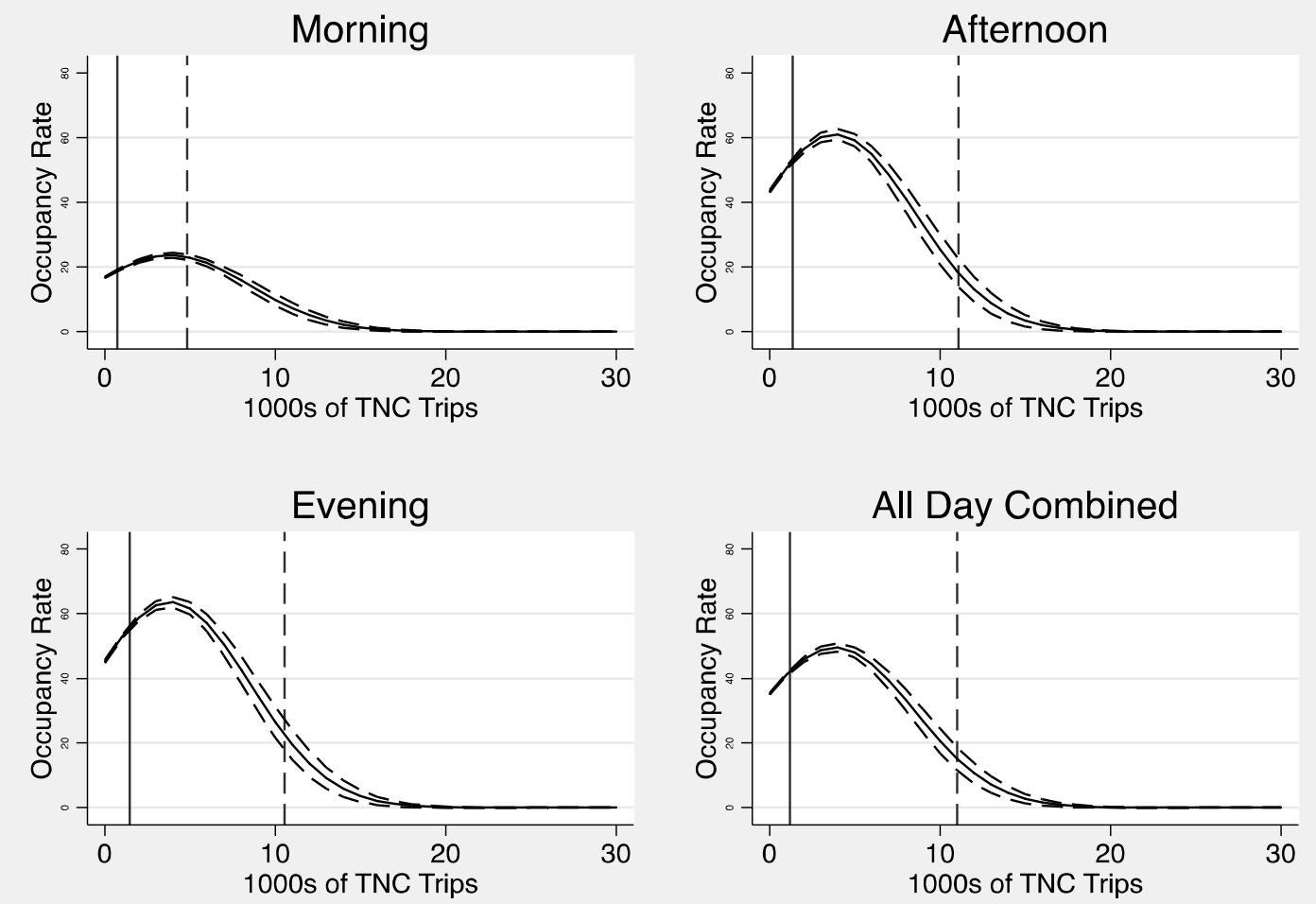

95\% Confidence Interval Shown with Dashed Lines

Solid vertical lines = mean \# of TNC trips; Dashed vertical lines = maximum observed \# of trips

Figure 4.1: TNC Trip Effects on Parking Occupancy

Solid vertical lines indicate mean number of TNC trips observed in data. Dashed vertical lines represent the maximum observed number of trips in the data; displayed curves to the right of the dashed vertical lines represent projections based on model results.

Results for per-space parking revenue (Model 3) are broadly similar to Model 2. The average per-space, on-street, paid parking revenue increases by 12.7 percent for each 1,000 additional TNC trips taken, all else equal. Again, the squared term is significant and negative and this non-linear relationship can be seen in Figure 4.3. In this model, statistically significant marginal effects are shown with a peak revenue of about 5,500 TNC trips, after which revenues begin to decline. 

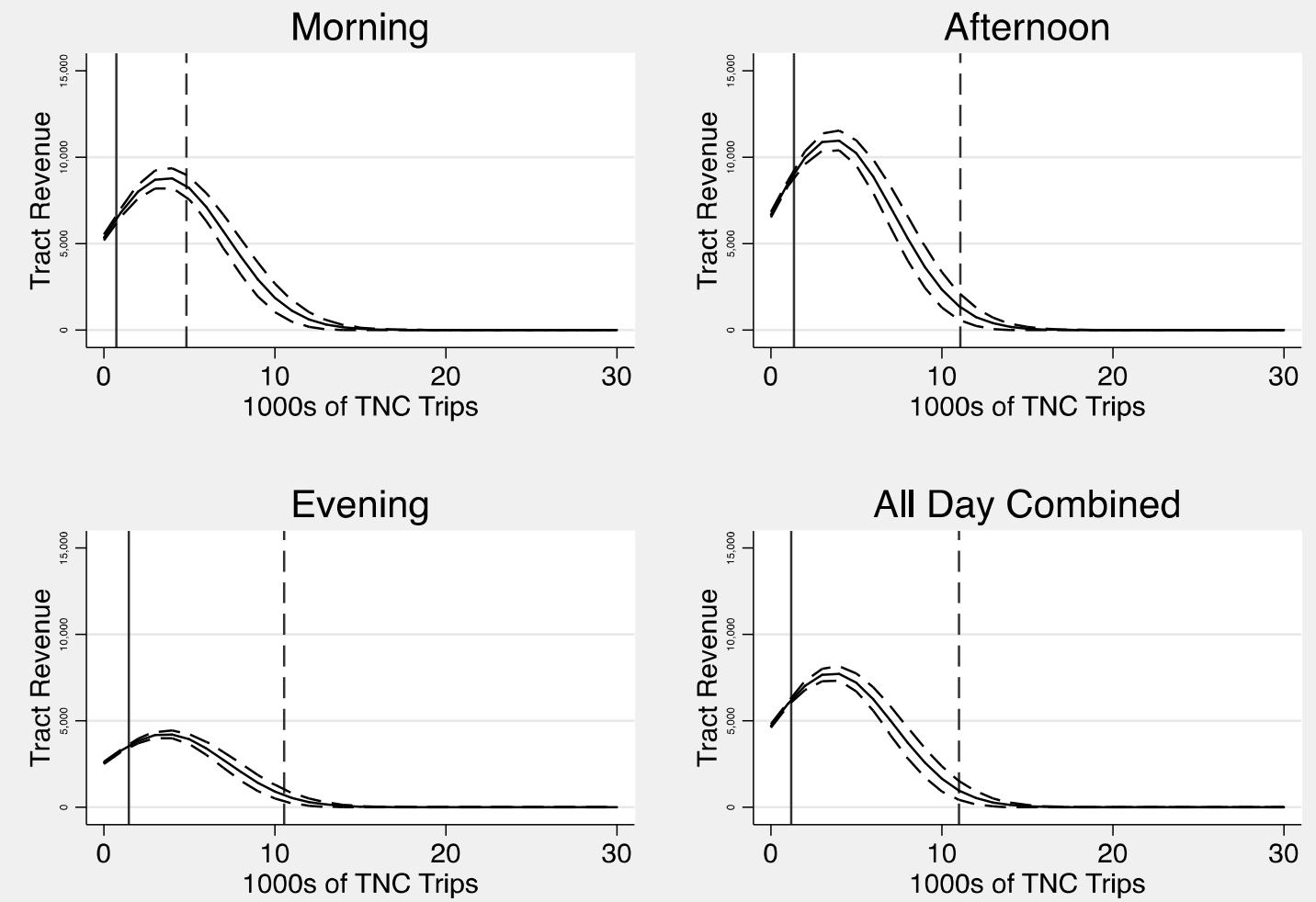

95\% Confidence Interval Shown with Dashed Lines

Solid vertical lines $=$ mean \# of TNC trips; Dashed vertical lines $=$ maximum observed \# of trips

Figure 4.2: TNC Trip Effects on Total Tract Revenue

Solid vertical lines indicate mean number of TNC trips observed in data. Dashed vertical lines represent the maximum observed number of trips in the data; displayed curves to the right of the dashed vertical lines represent projections based on model results. 

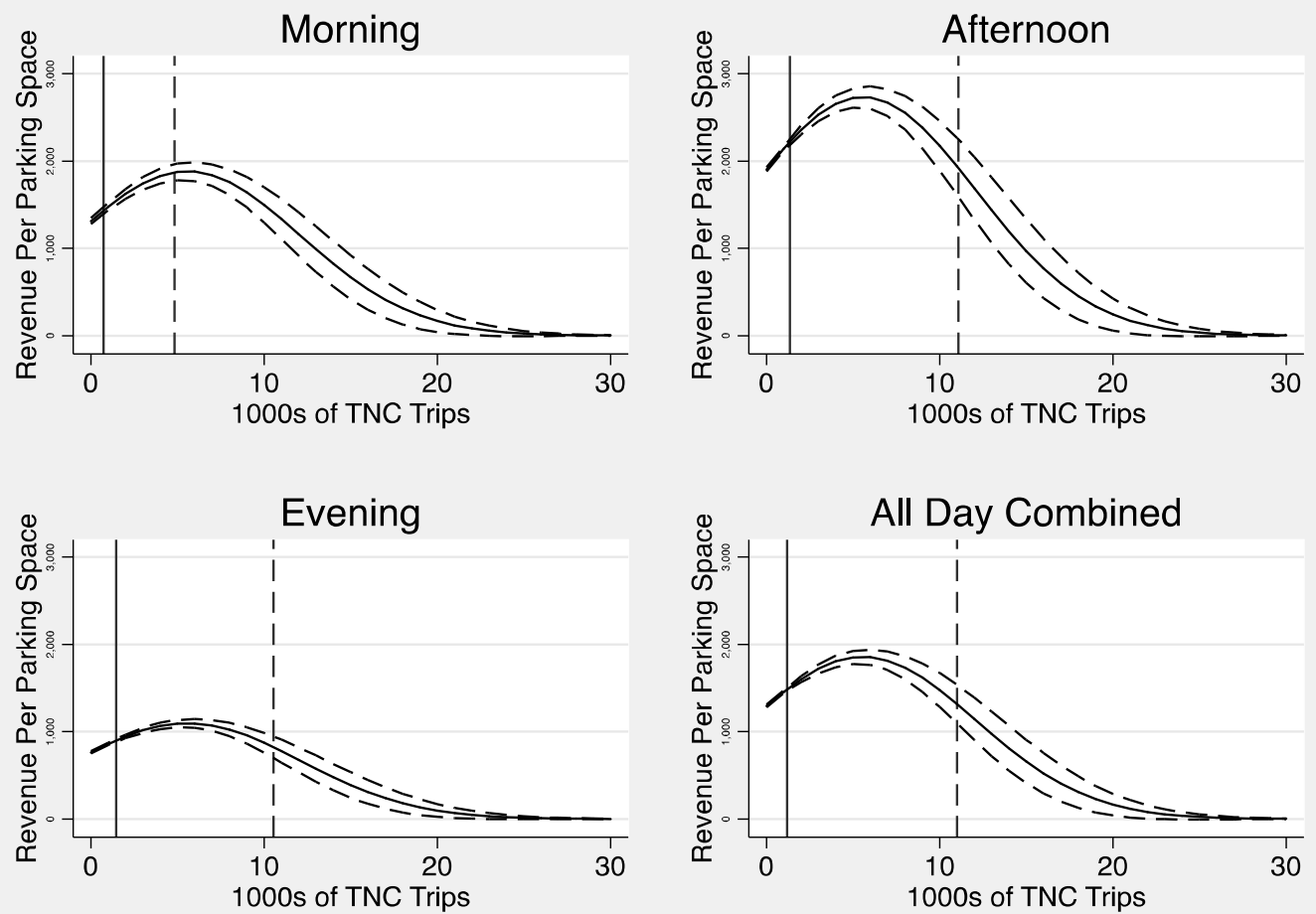

95\% Confidence Interval Shown with Dashed Lines

Solid vertical lines = mean \# of TNC trips; Dashed vertical lines = maximum observed \# of trips

Figure 4.3: TNC Trip Effects on Average Revenue Per Parking Space

Solid vertical lines indicate mean number of TNC trips observed in data. Dashed vertical lines represent the maximum observed number of trips in the data; displayed curves to the right of the dashed vertical lines represent projections based on model results.

On-Street Median Occupancy Rate: In both parking revenue models (Models 2 and 3), we control for the parking occupancy rate (the dependent variable in Model 1). Results from both Models 2 and 3 show that for each additional percentage increase in occupancy, revenue increases by 2.3 or 2.4 percent, respectively.

Average Cost to Park On-Street Per Hour: Model predictions show that as the cost of parking on the street increases by an average of $\$ 1 /$ hour, the overall occupancy decreases by 5.5 percent. The results in Models 2 and 3 demonstrate that raising onstreet parking prices by $\$ 1 /$ hour would increases total and per-space revenue by about 18.7 and 48.2 percent, respectively. Figure 4.4Figure 4.4 shows the relationship between parking prices and total tract revenue (Model 2); the relationship holds across different times of the day. 

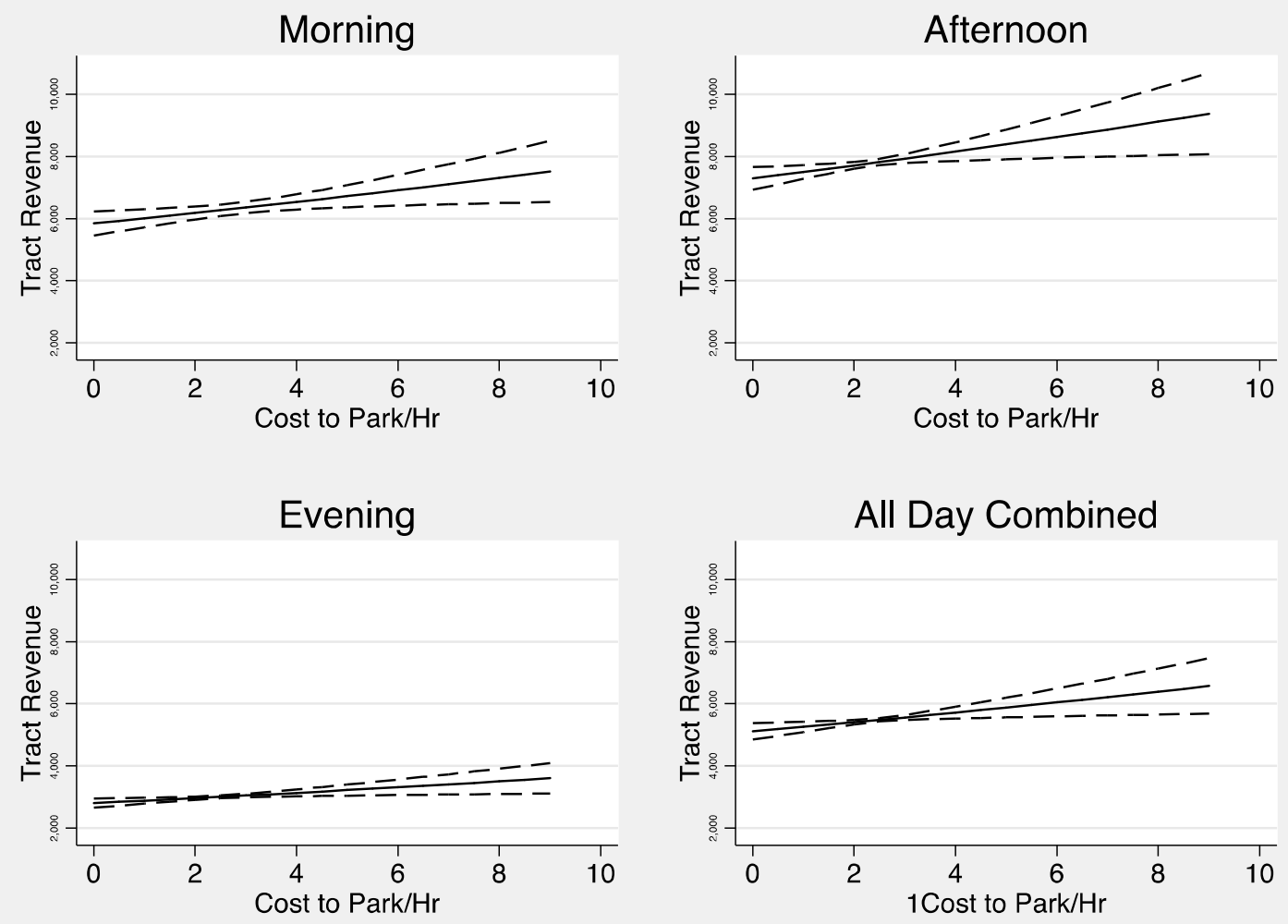

95\% Confidence Interval Shown with Dashed Lines

Figure 4.4: Hourly Price to Park Effects on Tract Revenue by Time of Day

Paid On-Street Parking Spaces: Model 1 results show that an increase of 100 paid onstreet parking spaces is associated in a 4.3 percent decrease in parking occupancy. This aligns with Model 3 , which shows that for every 100 additional paid on-street parking spaces per space revenue falls by 4.3 percent. These results contrast to Model 2 (total revenue), in which we find that an additional 100 paid on-street parking places are associated with a 30.7 percent increase in total tract revenue. The contrasting associations likely reflect that additional parking spaces may increase the overall revenue that the city collects, but simultaneously reduces demand for any one spot, thus decreasing per-space revenues.

Paid Off-Street Parking Spaces: Off-street parking inventory is negatively associated with parking occupancy and total revenue collected; it does not, however, affect perspace revenue. As the inventory of paid off-street parking increases by 100 spaces, parking occupancy falls by 0.4 percent, and total revenue falls by 0.2 percent. Figure 4.5 provides a visual representation of this relationship in Model 2. 

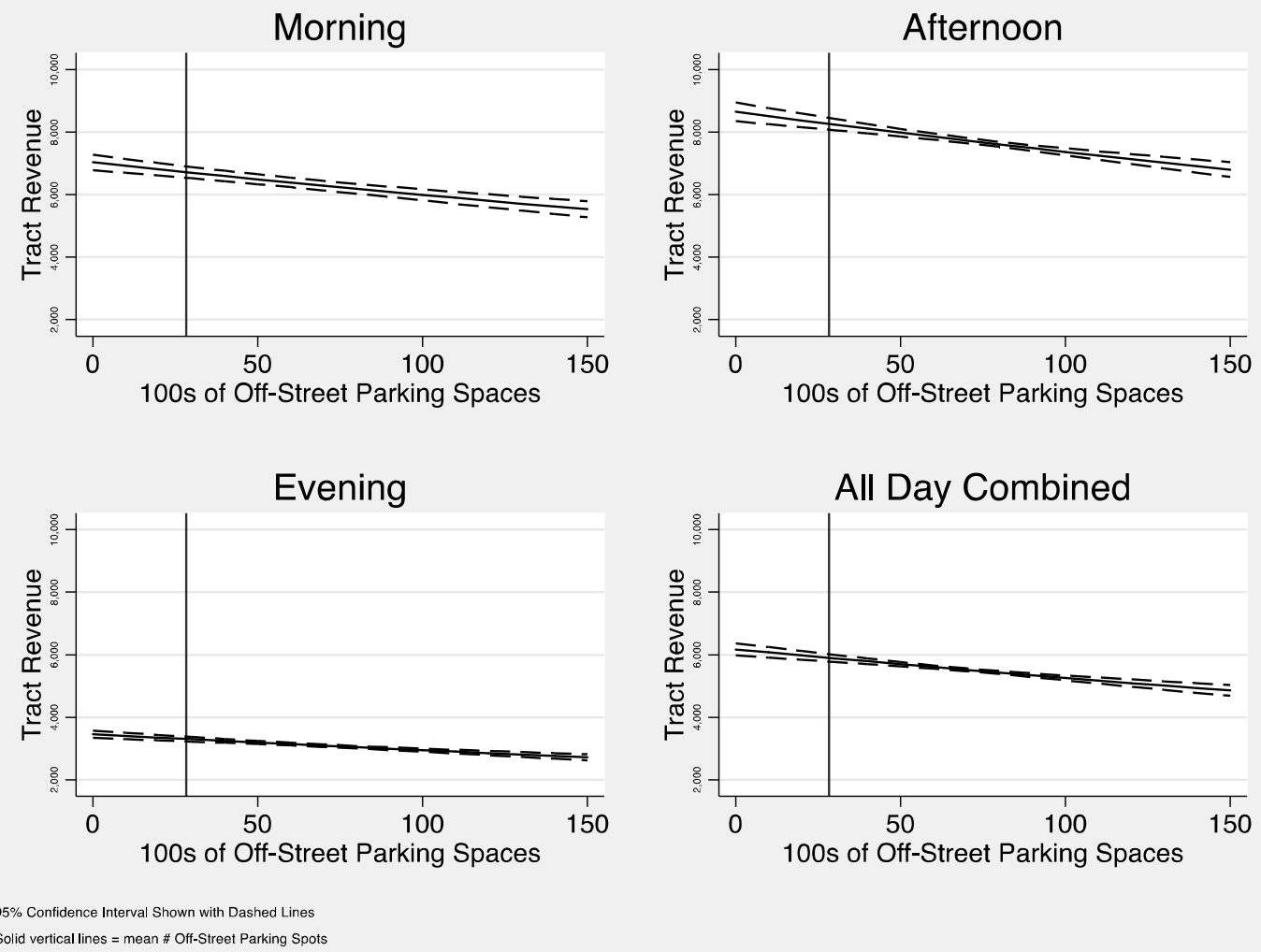

Figure 4.5: Number of Off-Street Parking Spaces Effects on Total Tract Revenue

The solid vertical line in each cell of this figure represents the mean number of off-street parking spaces in a census tract.

Number of Vehicles - Cars, Trucks, Vans: The number of vehicles owned in a tract is negatively related to parking occupancy rate, total, and per-space revenue. Results indicate a 0.9 percent decrease in parking occupancy for each 100 additional vehicles owned in a tract. Each 100 additional vehicles owned in a tract is associated with a decrease in total and per-space revenue by 2.1 percent and 1.4 percent, respectively.

Transit Stops Per Square Mile: Transit stops per square mile is negatively associated with on-street parking occupancy, showing an additional stop per square mile is associated with a 11.2 percent decrease in parking occupancy. This may be a function of increased mode choice options in these neighborhoods. Additionally, it should be noted that the cost to park and the number of stops are positively correlated with each other $(r=0.5)$, thus the density of public transit and parking cost are working in the same direction. Number of transit stops per square mile is also negatively associated with perspace revenue; each additional stop per square mile is associated with 1.3 percent decrease in per-space revenue. In contrast, density of the public transportation network is positively associated with total parking revenue, and each additional stop per mile is associated with a 15.8 percent increase in total tract revenue-again likely due to the density of the network and cost per hour being positively related to one another. Figure 
4.6 shows the relationship between transit stop density and average per space revenue (Model 3); the pattern of association holds across times of the day.
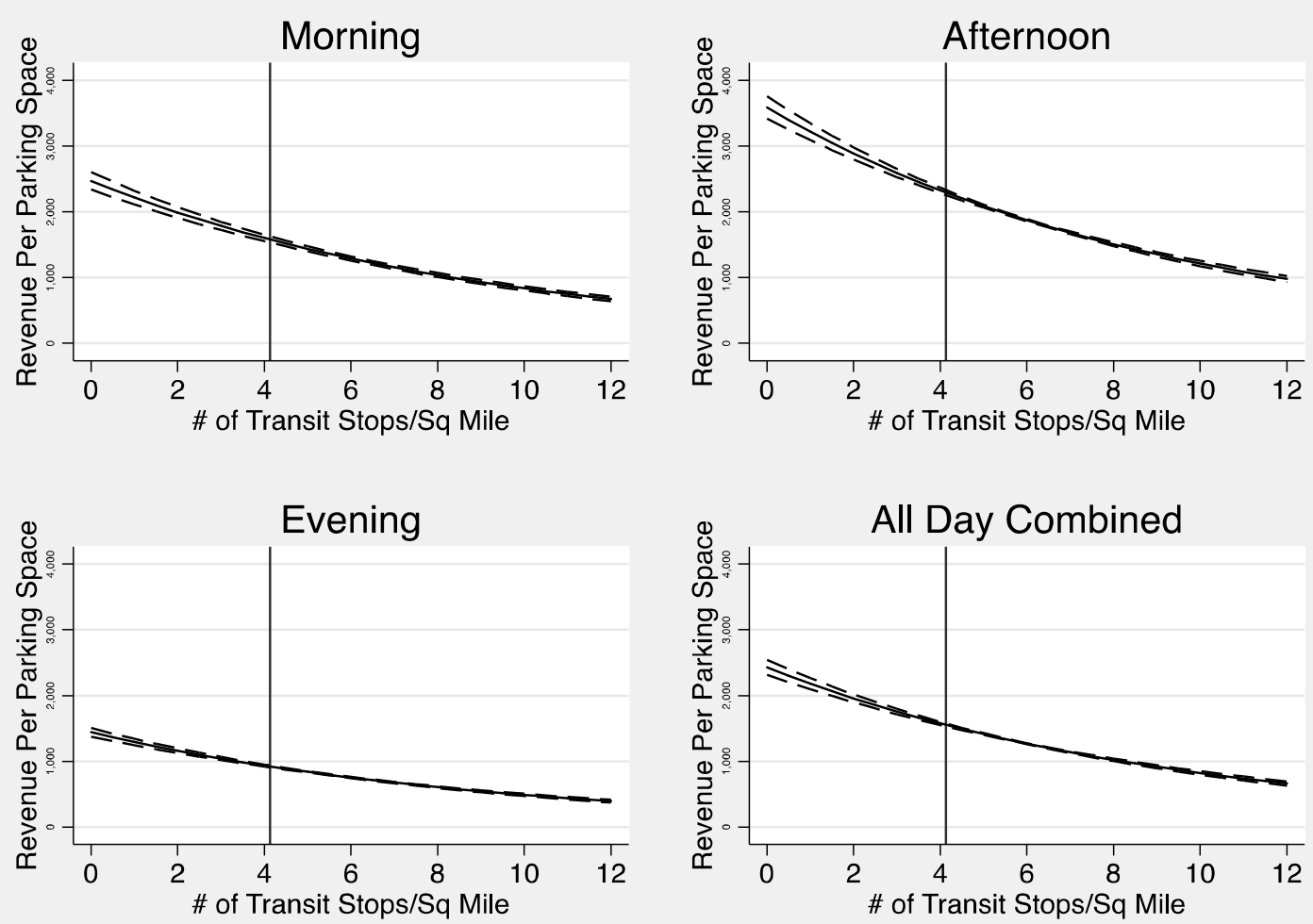

95\% Confidence Interval Shown with Dashed Lines

Solid vertical lines $=$ mean $\#$ of transit stops

Figure 4.6: Associations between Transit Stops Per Square Mile and Per-Space Parking Revenue by Time of Day

The solid vertical line in each cell of this figure represents the mean number of transit stops/square mile in a census tract.

Number of Parking Citations: For each additional 100 parking citations issued in a tract, parking occupancy increases by 5.8 percent. This may relate to more citations being issued in areas that have a higher demand for parking, thus creating more parking violations and/or opportunities to issue citations. The number of parking citations in a tract is negatively related to total and per-space, on-street parking revenue. An increase of 100 parking citations is associated with a 1.1 and 3.2 percent decrease in total and per-space revenue, respectively.

Median Household Income: Tract median household is positively associated with parking occupancy, but negatively associated with total and per-space parking revenue. A $\$ 1,000$ increase in the median household income in a tract is associated with a 0.7 percent increase in parking occupancy. This finding is likely related to the fact that as income increases, the likelihood for off-street parking would also increase. These two variables have a statistically significant correlation $(r=0.11)$. Income is, however, negatively related to parking revenue. We find an additional $\$ 1,000$ in median 
household income is associated with 1.1 and 0.9 percent less total and per space revenue, respectively. It should be noted that the relationship between the average cost to park per hour is negatively related with household income $(r=-0.25)$; in other words, parking appears to be cheaper in neighborhoods with higher household incomes.

Population Density: Every additional 1,000 people per square mile is associated with a 3.3 percent decline in parking occupancy. It could be that denser areas also have more opportunities for active and public transportation, thus needing less parking. We could also surmise that the areas with greater population density, also have more land devoted to residential zoning (statistically significant relationship, $r=0.4$ ), thus less of a need for commercial/retail oriented on-street parking. The same increase in population density is associated with a 3 percent increase in total tract revenue and a 1.9 percent increase in per space parking revenue.

Zoning \& Land Use: All three models highlight the role that land use plays in the demand for parking and the revenue it generates. In Model 1 (parking occupancy) we find all of our land use variables are statistically significant when compared to the omitted category (percentage of land in the tract zoned for commercial use). Compared to commercial land use, tracts with higher shares of residential, industrial and other-use land have lower parking occupancy; by contrast, tracts with higher shares of mixed-use land have higher parking occupancy, all else equal. A similar pattern emerges when we look to total and per-space parking revenues. For the most part, the more land that is devoted to commercial uses, the more total and per-space revenue is generated; this is likely because metered parking areas tend to be in commercially zoned districts. A oneunit or one-percent increase in residential land use reduces total revenue by 0.4 percent and per-space revenue by 0.1 percent. A one-percent increase in mixed-use land is associated with a 1.8 percent decrease in total revenue, but a 0.4 percent increase in per-space revenue. Finally, a 1 percent increase in other zoning/uses is associated with 1.1 and 0.3 percent declines in total and per-space revenue, respectively. Land zoned for industrial uses sees a 0.5 percent increase in total revenue for a 1 percent increase in that land use compared to commercial use.

Other Controls: Controls for time of day, the day of the week, and year reveal significant associations with parking occupancy and revenues. Afternoons have greater levels of occupancy and revenue generated than mornings, likely owing to more businesses being open after the end of the morning time category (10 a.m.). Total and per-space revenue, however, is lower in the evenings (4-7 p.m.) compared to the morning (8-10 a.m.). Mondays have the lowest levels of occupancy and revenue when compared to all other days in which on-street parking is charged for; parking occupancy and revenues are higher in the second half of the week. After controlling for other variables, parking occupancies and revenues have fallen slightly over time. 


\subsection{DISCUSSION AND CONCLUSION}

The results of the analysis suggest that, while parking occupancy and revenues may not fall at current rates of TNC use, cities should prepare policies to adapt to an uncertain autonomous future. Seattle, like many cities, does not set parking rates to maximize revenue. Yet parking revenues are critical to financial stability within the City budget. In the City's 2018 budget, parking meter revenue accounted for about 3 percent of general fund revenue, or about $\$ 44$ million, this share of general fund revenue has remained relatively stable over the past five years (City of Seattle, 2018).

Our report findings suggest that-at least at current trip levels-TNC use will not decimate either total or per-space parking revenue in cities. Model results do, however, suggest that as trip volumes increase, revenues may decline. Model predictions show that parking revenues will decline if or when TNC (or possibly AV) trips are about three times greater than the average number of daily trips taken in 2016. Observed on-street maximum parking occupancy rates also indicate that we are closer to peak parking (revenue) than these predictions would otherwise indicate. This suggests that, while some travelers may hail a TNC in lieu of driving, modal substitution is not yet resulting in parking revenue losses overall, although it is getting closer. Instead, rather than TNCs reshuffling a fixed number of travelers into a different modal mix-more people are traveling to and from destinations using a combination of modes, including both personal vehicles and TNCs. In other words, TNCs and driving, which at first blush seem to be classic substitutes, may in fact be complementary by enabling more people to travel to/from locations on preferred routes, times, and modes. The data used in this study do not provide insight into which TNC trips substitute for personal driving, which carry people who previously traveled by other modes or at other times of the day, or which are new trips entirely. Additional research is needed to better understand the potential mode shift dynamics between driving, TNCs, and other modes.

The analysis presented in this report assumes no policy action by cities. Current City of Seattle parking policy aims to maintain an on-street occupancy rate between 70 and 85 percent (Baruchman, 2018). If occupancy begins to fall with much higher levels of TNC (or AV) use, cities may have to consider policy alternatives. One option would be to lower parking prices to reflect lower demand for parking. Lowered prices would erode parking revenues, but, importantly, may also counter many cities' efforts to encourage car-alternative travel. Instead of lowering prices to rebalance parking supply with demand, cities could instead maintain parking prices but reduce their on-street parking supply repurposing on-street spaces for other uses such as parklets, loading spaces, or non-auto parking spaces. This action would also likely reduce total parking revenues, but may produce ancillary benefits such as managing congestion through additional loading spaces, facilitating micromobility with additional non-auto parking spaces, or enhancing the streetscape and useable outdoor space with parklets. Many cities are already experimenting with alternative uses for parking spaces: Washington, D.C., recently completed an on-demand, curb-space reservation pilot for a variety of commercial uses including TNCs, food deliveries, and commercial deliveries (District Department of Transportation, 2019); Boston, too, is experimenting with similar pilots 
with some success (Short, 2019). In both cases, the city replaced traditional parking revenue with another source (loading zone reservations) while simultaneously addressing congestion issues.

Per-space parking revenues in Seattle were highest in commercial and mixed-use areas, and model results show that increasing residential and other land uses slightly reduces total parking revenue relative to commercial and all else equal. This may indicate that cities should, in the longer run, focus policy efforts on commercial and mixed-use areas for more revenue opportunities since they are projected to have larger revenue shortfalls. Finding replacements for these revenues, such as the piloted projects in Washington, D.C., or Boston, could help offset projected revenue losses, but may not be a panacea.

Model results for both total and per-space revenue show that the built environment including land use and population density have relatively small associations with revenue compared to the broader temporal and transportation context: time of day, number of parking spaces, and parking price all have strong associations with parking revenue. This finding affords a policy opportunity across land uses. Policymakers and planners can adjust parking prices or policies by time of day or day of week to achieve desired occupancies or outcomes. Other researchers suggest setting occupancy goals instead of attempting to maximize revenue, which may result in underutilized parking (Pierce, Willson, and Shoup, 2015).

Cities are not in immediate danger of losing parking revenues due to TNCs, and parking demand will not disappear overnight. Nevertheless, cities should practice scenario planning to understand revenue implications as people take more TNC trips-and eventually AVs -in the coming years. Dynamic analyses are needed to assess how parking rates change in response to higher TNC use, and how those changes paired with one another could affect parking revenues. 


\subsection{REFERENCES}

Baruchman, Michelle. 2018. "New On-Street Parking Rates Are Coming to Seattle Neighborhoods. Here's What You'll Pay | The Seattle Times." Seattle Times, November 23, 2018. https://www.seattletimes.com/seattlenews/transportation/new-on-street-parking-rates-are-coming-to-seattleneighborhoods-heres-what-youll-pay/.

Bergal, Jenni. 2017a. "Airport Parking Takes Hit From Uber, Lyft." 2017. http://pew.org/2t98Rmr.

— . 2017b. "Uber, Lyft Cut Into Parking Revenue That Keeps Airports Running." 2017. http://www.governing.com/topics/transportation-infrastructure/sl-uber-lyftairports.html.

Brodsky, Jessica S. 2016. "Autonomous Vehicle Regulation: How An Uncertain Legal Landscape May Hit The Brakes On Self-Driving Cars." Berkeley Technology Law Journal 31: 851-78.

Brown, Anne. 2019. "Redefining Car Access." Journal of the American Planning Association 85 (2): 83-95. https://doi.org/10.1080/01944363.2019.1603761.

City of Seattle, Washington. 2018. "2018 Adopted Budget--General Subfund Revenue Overview." City Budget Office, City of Seattle. http://www.seattle.gov/financedepartment/18adoptedbudget/documents/revenue overview.pdf.

Clark, Benjamin Y. 2019. "How Will Autonomous Vehicles Change Local Government Budgeting and Finance? Case Studies of On-Street Parking, Curb Management, and Solid Waste Collection." NITC-SS-1174. Portland, OR: Transportation Research and Education Center (TREC). https://nitc.trec.pdx.edu/research/project/1174.

Clark, Benjamin Y., and Anne Brown. 2020. "HOW ARE UBER/LYFT SHAPING MUNICIPAL ON-STREET PARKING REVENUE?" SSRN Scholarly Paper ID 3591268. Rochester, NY: Social Science Research Network. https://papers.ssrn.com/abstract=3591268.

Clark, Benjamin Y., Nico Larco, and Roberta F. Mann. 2017. "The Impacts of Autonomous Vehicles on Local Government Budgeting and Finance." SSRN Scholarly Paper ID 3009840. Rochester, NY: Social Science Research Network. https://papers.ssrn.com/abstract=3009840.

Clark, Benjamin Y., and Rebecca Lewis. 2018. "Future Transport and City Budgets: Getting Bottom-Line Savvy In An Uncertain Future." In Disruptive Transport: Driverless Cars, Transport Innovation and the Sustainable City of Tomorrow, 1st Edition (Hardback) - Routledge, edited by William Riggs. Routledge. https://www.routledge.com/Disruptive-Transport-Driverless-Cars-TransportInnovation-and-the-Sustainable/Riggs/p/book/9781138613164.

Clewlow, R., and G. Mishra. 2017. "Disruptive Transportation: The Adoption, Utilization, and Impacts of Ride-Hailing in the United States. Institute of Transportation Studies, University of California." Davis, Research Report UCD-ITS-RR-17-07. https://itspubs.ucdavis.edu/wpcontent/themes/ucdavis/pubs/download_pdf.php?id=2752. 
Connery, Brian. 2016. "Autonomous Vehicles and Municipal Bonds." New York, NY: Morgan Stanley.

District Department of Transportation. 2019. "DDOT, CurbFlow Research Project Finds High Demand for Pickup, Dropoff Zones | Ddot." November 13, 2019.

https://ddot.dc.gov/release/ddot-curbflow-research-project-finds-high-demandpickup-dropoff-zones.

Fagnant, Daniel J., and Kara Kockelman. 2015. "Preparing a Nation for Autonomous Vehicles: Opportunities, Barriers and Policy Recommendations." Transportation Research Part A: Policy and Practice 77 (July): 167-81. https://doi.org/10.1016/j.tra.2015.04.003.

Freemark, Yonah, Anne Hudson, and Jinhua Zhao. 2019. "Are Cities Prepared for Autonomous Vehicles?" Journal of the American Planning Association 85 (2): 133-51. https://doi.org/10.1080/01944363.2019.1603760.

Glancy, Dorothy J. 2015. "Autonomous and Automated and Connected Cars - Oh My: First Generation Autonomous Cars in the Legal Ecosystem." Minnesota Journal of Law, Science and Technology 16: 619.

Glus, Peter, Tanya Bhatia, Caroline Caglioni, Leland Greenfield, Ellie Killiam, Anna Kramer, Mary Penny, et al. 2017. "Driverless Future: A Policy Roadmap for City Leaders." 01633241. https://www.arcadis.com/en/united-states/ourperspectives/driverless-future/.

Gould, William. 2011. "The Stata Blog » Use Poisson Rather than Regress; Tell a Friend." The Stata Blog (blog). August 22, 2011. http://blog.stata.com/2011/08/22/use-poisson-rather-than-regress-tell-a-friend/.

Gutman, David. 2018. "Study Shows Seattle Has Plenty of Parking. So Why Can't You Find a Spot? | The Seattle Times." Seattle Times, July 14, 2018. https://www.seattletimes.com/seattle-news/transportation/study-shows-seattlehas-plenty-of-parking-so-why-cant-you-find-a-spot/.

Harb, Mustapha, Yu Xiao, Giovanni Circella, Patricia L. Mokhtarian, and Joan L. Walker. 2018. "Projecting Travelers into a World of Self-Driving Vehicles: Estimating Travel Behavior Implications via a Naturalistic Experiment." Transportation 45 (6): 1671-85. https://doi.org/10.1007/s11116-018-9937-9.

Henao, Alejandro. 2017. "Impacts of Ridesourcing - Lyft and Uber - on Transportation Including VMT, Mode Replacement, Parking, and Travel Behavior - ProQuest." Denver, CO: University of Colorado at Denver. https://search.proquest.com/openview/5486ff6cc229889a3cdf2df1cd3993cb/1?p q-origsite $=$ gscholar $\& \mathrm{cbl}=18750 \&$ diss $=\mathrm{y}$.

Henao, Alejandro, and Wesley E. Marshall. 2019. "The Impact of Ride Hailing on Parking (and Vice Versa)." Journal of Transport and Land Use 12 (1). https://doi.org/10.5198/jtlu.2019.1392.

Lewis, Paul, Gregory Rogers, and Stanford Turner. 2017. "Beyond Speculation Automated Vehicles and Public Policy." Washington, D.C.: Eno Center for Transportation. https://www.enotrans.org/wpcontent/uploads/2017/04/AV_FINAL.pdf.

Maciag, Mike. 2017. "How Driverless Cars Could Be a Big Problem for Cities." Governing Magazine. August 1, 2017. 
http://www.governing.com/topics/finance/gov-cities-traffic-parking-revenuedriverless-cars.html.

Mahmoudi, Jina, and Lei Zhang. 2009. "The Relationship between For-Hire Service Pickups and Built Environment Characteristics: Evidence from New York City." Journal of Transportation Engineering. https://doi.org/10.1061/9780784481530.001.

Mitteregger, Mathias, Aggelos Soteropoulos, Johann Bröthaler, and Fabian Dorner. 2019. "Shared, Automated, Electric: The Fiscal Effects of the "Holy Trinity." In REAL CORP 2019-IS THIS THE REAL WORLD? Perfect Smart Cities vs. Real Emotional Cities. Proceedings of 24th International Conference on Urban Planning, Regional Development and Information Society, 627-635. CORPCompentence Center of Urban and Regional Planning.

Morris, David Z. 2018. "Yes, Uber Really Is Killing The Parking Business." Fortune. February 24, 2018. https://fortune.com/2018/02/24/yes-uber-really-is-killing-theparking-business/.

National League of Cities. 2017. "Autonomous Vehicles: A Policy Preparation Guide." Washington, D.C.: Center for City Solutions, National League of Cities. http://www.nlc.org/sites/default/files/201704/NLC\%20AV\%20Policy\%20Prep\%20Guide\%20web.pdf.

Pierce, Gregory, Hank Willson, and Donald Shoup. 2015. "Optimizing the Use of Public Garages: Pricing Parking by Demand." Transport Policy 44 (November): 89-95. https://doi.org/10.1016/j.tranpol.2015.07.003.

San Francisco County Transportation Authority. 2017. "TNCs Today: A Profile of San Francisco Transportation Network Company Activity." San Francisco, CA. https://www.sfcta.org/sites/default/files/2019-02/TNCs_Today_112917_0.pdf.

Scharnhorst, Eric. 2018. "Quantified Parking: Comprehensive Parking Inventories for Five US Cities." Research Institution for Housing America.

https://www.documentcloud.org/documents/4598972-RIHA-Parking-Report.html.

Seattle Department of Transportation. 2017. "NEW MOBILITY PLAYBOOK." Seattle, WA: Seattle Department of Transportation. https://newmobilityseattle.info/storage/app/media/Documents/newmobilityplayboo kfurtheractionsappendices.pdf.

Short, Aaron. 2019. "Three Cities See a Way to 'Curb' Traffic." Streetsblog USA (blog). December 11, 2019. https://usa.streetsblog.org/2019/12/11/three-cities-see-away-to-curb-traffic/.

Shoup, Donald. 2011. The High Cost of Free Parking, Updated Edition. 1 edition. Chicago: Routledge. 2017. The High Cost of Free Parking: Updated Edition. Routledge. https://doi.org/10.4324/9781351179782.

Silva, JMC Santos, and Silvana Tenreyro. 2006. "The Log of Gravity." The Review of Economics and Statistics 88 (4): 641-658.

Terry, Jacob, and Chris Bachmann. 2019. "Quantifying the Potential Impact of Autonomous Vehicle Adoption on Government Finances." Transportation Research Record, April, 0361198119837218. https://doi.org/10.1177/0361198119837218. 
Williamson, Richard. 2018. "Airports, Facing Competition Enhance Parking Technology for Competition with Uber, Lyft." Bond Buyer. 2018.

https://www.bondbuyer.com/news/airports-guard-parking-revenues-against-ridehailing-services.

Willson, Richard W. 2013. Parking Reform Made Easy. Island Press.

Woolridge, J. M. 2002. Econometric Analysis of Cross Section and Panel Data. Cambridge, MA: MIT Press. 